\title{
Karl Marx, Class Struggle and \\ Labour-Centred Development
}

\author{
Benjamin Selwyn, University of Sussex, UK
}

\begin{abstract}
Karl Marx has often been interpreted as formulating an economic determinist, Eurocentric and historically linear conception of human development. Where they exist, such interpretations understand 'development' as capitalist modernisation. If correct, this critique leaves Marxism illequipped to interpret and contribute to transformations of the conditions of labouring classes under neoliberal globalisation. This article argues against such interpretations by discussing how, for Marx, the form and content of class struggles, their relations to the national state, and their articulation through the world system were the key to understanding divergent processes of human development. Marx's insights are particularly relevant under contemporary globalised capitalism. This article argues, further, that Marx provides us with the basis for formulating a labour-centred approach to human development and development studies.
\end{abstract}

\section{KEYWORDS}

capitalism, development studies, Eurocentrism, globalisation, Karl Marx, labour-centred development, labouring classes, neoliberalism

\section{Introduction}

The collapse, in 1989 and 1991, of the Eastern European and Russian regimes signified for many the end of socialism, the end of history, the irrelevance of Marx's critique of capitalism and his conception of a post-capitalist alternative. But Marx did not disappear. Instead he was adopted, by many on left and right, as a prophet of capitalist globalisation. For example, Financial Times columnist Martin Wolf (2004: 174) describes Marx's analysis of global capitalist expansion as 'forward looking', and contrasts it to 'reactionary' movements opposed to global institutions such as the World Trade Organisation.

There is much in Marx, particularly in a few famous pages of the Communist Manifesto (written in 1848, when Marx was just 29, and before the disappointments of the European bourgeois revolutions of that year) that portrays capitalism in glowing and progressive terms. There are also other parts of Marx's work which were taken up and formalised by traditions of Marxism (ranging from the Second to the ossified Third International under Stalin) that explained human history in mechanistic, linear terms.

More than these political and intellectual traditions, the history of Stalinism and Maoism - the deaths of tens of millions of peoples as Russia and China respectively attempted to achieve 
'socialist' industrialisation and catch-up with the West - represent developmental dead ends, never, hopefully, to be repeated. That these regimes proclaimed themselves as 'Marxist', 'communist' and 'socialist' repels many from investigating Marx's writings and their implications for contemporary and potentially post-capitalist development.

However, there is a body of literature that demonstrates that the cases of 'really-existing socialism' were in fact forms of 'state capitalism'. This literature suggests that socialism should not be equated with Stalinism or Maoism, that the heart of socialism resides in struggles by laboring classes from below, and that if we are concerned with understanding the potential for alternative forms of human development, then we should look to such struggles. The literature includes Cliff (1974) on Russia, Harman (1974) on Eastern Europe, Hore (1991) on China, Binns and Gonzalez (1980) on Cuba, and Zeilig (2010) on myriad Sub-Saharan African cases. These writers show how following the model of Stalinist Russia, new ruling classes used the state as a tool of capital accumulation based upon the exploitation of their countries' working classes and peasantries to compete in, and attempt catch-up with more advanced capitalist countries in the world system. These states were subject to the same competitive pressures as other states and firms in the world system which in turn required the same strategies based upon competitive capital accumulation: consumption subordinated to accumulation, and accumulation driven by externally determined competition based upon the repression and exploitation of labour.

Contemporary development discourse is dominated by the (falsely dichotomous) marketled vs. state-led debate. Both approaches are essentially elitist. They relegate human development to second place and prioritise combinations of capital accumulation and the augmentation of state power. As Burkett and Hart-Landsberg $(2003,148)$ argue, 'the catch-up vision [of development]...simply presumes that the primary role of working people and their material and social conditions is to serve as instruments and vehicles of capital accumulation and economic growth'. ${ }^{1}$ Contemporary China is perhaps the most pertinent example of how combinations of state and market-led development rest upon the intense exploitation of labour.

In contrast to elite understandings of development, including the state capitalist variants, this article argues that Marx's work provides the basis for comprehending an alternative, labourcentred conception of human development. Labouring classes and their struggles against exploitation by capital are politically prioritised, and are conceptualised as 'developmental' because they can deliver improvements to workers' livelihoods.

Marx and Engels were committed to a vision of human development centred upon the actions of the majority. For example, in the Communist Manifesto they wrote how 'Communism deprives no man of the power to appropriate the products of society; all that it does is to deprive him of the power to subjugate the labour of others by means of such appropriations' ${ }^{2}$ Whilst they understood that a communist or socialist society would require a revolution against existing capitalist society, they did not limit themselves to speculating about human development in a hypothetical socialist future. They also enquired into what kinds of struggles by labouring classes could better their conditions under capitalism.

This article is structured as follows. The following section provides a brief description of some of the main transformations experienced by labouring classes under neoliberal globalisation. Section three argues against economic determinist and Eurocentric interpretations of Marxism. Section four provides the basis for an alternative, conjunctural and class-relational conception of human development, rooted in Marx's writings. This alternative reading is deepened in section five. Section six concludes the article. 


\section{Labouring Classes Under Neoliberal Globalisation}

This section argues that in their expansion under contemporary globalisation, capital and labour have simultaneously been globally dispersed and functionally integrated. This two-sided process generates, for both parties, new strengths and weaknesses. Capital is able to establish global networks of production and global wage hierarchies, the better to exploit and demobilise labour. However, as a consequence of continued capitalist expansion, the global labouring class is also growing, and is experiencing similar conditions across the globe which potentially makes it easier for geographically and culturally distant workers to identify with each other's (exploitative) conditions and struggles against exploitation. Furthermore, through the global production networks created by capital, labour finds new sources of structural power with which to disrupt capital accumulation. Whilst capital is the dominant actor in this exploitative relationship, it is not all-powerful.

Over the last four decades or so there has been an enormous expansion of the global labouring class. Freeman $(200: 1,14)$ calculates that the global 'labour pool' roughly doubled in size between the late 1980 s to the early 2000 s - from 1.46 billion to 2.93 billion people. The term labouring class refers to 'the growing numbers... who now depend - directly and indirectly on the sale of their labour power for their own daily reproduction' (Panitch and Leys 2001: ix, cited in Bernstein 2010: 8).

It is common to observe that the proliferation of global production networks entails a simultaneous dispersal and functional integration of units of capital across the globe (Gereffi 2001). It is also common to argue that through its globalising tendencies, capital can undermine labour's bargaining power (Hardt and Negri 2000). However, and less commented upon, is that the global labour pool, whilst geographically dispersed and divided along many lines, is also integrated by capital's globalising tendencies. Capital and labour's global, functional integration, represents a double-edged sword for both actors. On the one hand labour is subject to capital's globalising pressures, including the threat of re-location and its ability to disperse production, to reduce wage costs and minimise labour solidarity. On the other hand the integration of capital and labour through global production networks generates new sources of structural power for labour in its attempts to better its conditions.

The global labouring class is fragmented along lines of income, ethnicity, gender, caste and race, formal or informal occupation, geographical location (urban/rural or north/south), and the extent of its dependence upon wage labour for its social reproduction. It includes a growing number of workers who exist outside the formal sector and who do not enjoy permanent, relatively secure employment (Standing 2011).

However, the global labouring class is also functionally integrated. For example, David Harvey (2010: 280) notes how 'the labour surplus in Mexico is crucial to the functioning of firms in the United States'. The functional integration of the global labour pool is a partial outcome of globalising capital's attempts to generate, and benefit from an international wage hierarchy which acts as a cost-down pressure on wages across the production network. ${ }^{3}$ An example of this was provided by Bernard and Ravenhill in their illustration of the strategic value of the wage hierarchy to TNCs in 1990s East Asia. In their study, a Japanese calculator producer/exporter (Jinbao) purposefully designed a regional production network across East Asia in order to reduce production costs and raise profitability: 
'The innovation behind the product, the brand name, and the marketing are Japanese. All key components for the calculators, such as liquid crystal displays and production equipment in the Thai factory such as insertion equipment, are imported from Japan. All procurement and administration are controlled from Taipei, and the management of the plan it Taiwanese. The labour is Thai'. (Bernard and Ravenhill 1995: 186)

The benefits of a global wage hierarchy, integrated through production networks, is reflected by the high rates of exploitation experienced by workers within these networks. For example, CAFOD (2004 30-34) recently reported how in China workers need to work an illegal number of overtime hours (15-16 hours per day under poor conditions) to earn the minimum wage, whilst in Thailand sub-contracted workers earn a 'minimum wage' that does not even cover their food and household expenses.

The functional integration of global labouring classes by globalising capital has been facilitated by the international institutions, as they attempt to heighten labour exploitation. Paul Cammack argues that the World Bank's objectives, as formulated in its annual World Development Reports, are 'to deliver an exploitable global proletariat into the hands of capital... to deny the poor any alternative, and to create a reserve army of labour that will enforce the disciplines of capitalist labour-markets across the greater part of humanity' (2002: 125).

Marx had already observed capital's globalising tendencies and their implications:

'If we now conceive this feverish agitation as it operates in the market of the whole world, we shall be in a position to comprehend how the growth, accumulation, and concentration of capital bring in their train an ever more detailed subdivision of labour... a process which goes on uninterruptedly, with feverish haste, and upon an ever more gigantic scale'. (Marx $1847)^{4}$

Global capitalist sub-division entailed, and entails, the establishment of diverse forms of industrial agglomeration across the capitalist world system with significant consequences for labouring class struggles. In his portrayal, in Capital, of Industrialising England and the global division of labour that it engendered, Marx focussed primarily on Manchester's giant system of factories and its large and concentrated working class. Harvey, however, argues that the industrial structure in Birmingham was quite different to Manchester as it was 'small-scale but assembled in such a way as to realise economies of agglomeration' (Harvey 2010: 215). Harvey also argues, in relation to contemporary processes of capitalist sub-division, that while 'South Korean industrialism since the 1960s has been Manchester-like...Hong Kong's has been more Birmingham-like' (ibid). These are only four examples of the diversity of the forms of capitalist industrialisation, past and present.

Globalising capital consists of giant TNCs that integrate myriad smaller units of capital, ranging from state-owned enterprises to tiny family-run workshops, into their global production networks. Different forms of integration into the capitalist world system require and result in new forms of fragmentation and integration of labour, and generates varied forms of labouring class resistance.

One consequence of these new forms of global integration is that political struggles by labouring classes take myriad forms. While large-scale 'Manchester-like' struggles may characterise China's Pearl River Delta, other regions of the world system experience different 
forms of economic organisation and social struggle. For example, a high-point in labouring class resistance to neo liberal capitalism have been the risings in Bolivia between 2002 and 2005. Here, unlike in China, and reflecting Bolivia's specific form of capitalist development, the risings did not consist of masses of factory workers. As Zibechi (2006) described:

'Classic trade unions hardly exist... There are two main forms of organisation [in the city of El Alto]. One is the neighbourhood assembly. There are 550 of these - one for each barrio... The assemblies come together in the Federation of Neighbourhood Assemblies of El Alto. This is the most important organisation - the one that led the uprisings of 2003 and $2005 \ldots$ The other main form of organisation is the trade association of market vendors, which is grouped together in the Workers' Regional Centre... The organisations are all territorial - they control an area, a barrio or a market'.

In October 2003 people used their territorial control by means of road blocks and control of the highways. They cut off the roads so gas and food couldn't get through to La Paz. ${ }^{5}$

A second consequence of the global integration of capital and labour is that TNCs' globally dispersed production networks generate new sources of workers' structural power, providing them with the ability to disrupt these networks, through short bursts of strike action at strategic 'choke points' (Dunn 2005 and Selwyn 2008).

Despite the best attempts by globalising capital, International Financial Institutions, and capitalist states to generate malleable labouring classes for exploitation by capital, these attempts have been, and are being met by various forms of resistance by labour. Silver and Zhang (2009) refer to China as the 'epicentre of world labour unrest'. Rebellions and revolutions against neoliberalism emerged first in Latin America at the beginning of the 2000s (cf. Webber 2011), and more recently across the Middle East (Hanieh 2011).

These and the above-mentioned struggles present new developmental opportunities for the world's labouring classes - within, against and potentially beyond capitalism. A task of a labour-centred development studies will be to try to comprehend the circumstances that give rise to such struggles, the forms they take, their capacity to ameliorate their participants' livelihoods under capitalism, and their potential to transcend capitalism and establish a post-capitalist developmental process. The remainder of this article suggests that by looking back at how Marx considered the struggles of his day to be developmental, we can begin to establish the basis of a labour-centred development studies.

\section{Economic Determinism and Eurocentrism ${ }^{6}$}

Marx and Marxism have been associated with Eurocentrism and economic determinism, where economic 'laws' determine the course of human history and where 'the economy' determines other spheres of human life such as politics, ideas and state actions. Once such a starting point is accepted other precepts can logically follow: A comprehension of capitalism as operating according to its essential 'laws of motion' that cannot be disregarded (or contravened); a linear (straight line) view of history, where all countries follow the same path, for example, through the five stages of human history (primitive communism, slavery, feudalism, capitalism, socialism); and a form of Eurocentrism, where the economically dynamic West 'delivers' development to the stagnant East. Criticising such an approach, Edward Said highlights Marx's 
early writings on India, arguing that 'every writer on the Orient [including Marx] saw [it] as a locale requiring Western attention, reconstruction and even redemption' (2003: 206) and that 'Marx succumbed to thoughts of the changeless Asiatic village' (Said 1993: 183). Similarly, Eisenstadt (2000: 1) writes that Marx (and Durkheim and Weber) 'assumed... that the cultural program of modernity as it developed in modern Europe and the basic institutional constellations that emerged there would ultimately take over in all modernizing and modern societies'. Hobson (2011: 115) argues that 'the Eurocentric cue in Marx's work emerges in his belief that European societies self-generate through an endogenously-determined linear development path according to their own exceptional properties...'.

There are indeed writings by Marx that can be construed as embodying such an approach. Far more damaging, however, such formulations were subsequently adopted and formalised by latter-day Marxists. Thus in early $20^{\text {th }}$ century Russia for example, Georgi Plekhanov argued that ' $[\mathrm{t}]$ he organisation of any given society is determined by the state of its productive forces', and that 'technical progress constitutes the basis of the entire development of humankind' (Plekhanov 1976: 33, cited in Kiely 1995: 17). In the same vein, an official (1963) Soviet text, 'fundamentals of Marxism' (cited in Kiely 1995: 14), states that:

'All peoples travel what is basically the same path... The development of society proceeds through the consecutive replacement, according to definite laws, of one socio-economic function by another'.

In his analysis of English colonialism in India, Marx appears to suggest that advanced nations' actions can assist 'backward' countries emerge from stagnation. And it is here that he is sharply criticised by Said and others, as embodying Eurocentrism. For example, writing about the impacts of British colonialism in India Marx wrote how:

'English interference.... dissolved these small semi-barbarian, semi-civilized communities, by blowing up their economical basis, and thus produced the greatest, and to speak the truth, the only social revolution ever heard of in Asia'. (Marx: 1853) ${ }^{7}$

Further, and most notoriously:

'England has to fulfil a double mission in India: one destructive, the other regenerating the annihilation of old Asiatic society, and the laying of the material foundations of Western society in Asia'. (ibid)

In the Communist Manifesto, Marx and Engels highlight the differences between capitalism's dynamism and pre-capitalist economic formations: 'The bourgeoisie cannot exist without constantly revolutionising the instruments of production, and thereby the relations of production, and with them the whole relations of society (Marx and Engels 1848). ${ }^{8}$ And further ' $[\mathrm{t}]$ he bourgeoisie has through its exploitation of the world market given a cosmopolitan character to production and consumption in every country (ibid).

If the above quotes genuinely represent Marx's conception of human development, then turning away from Marx would represent a minimal loss. Indeed, Ray Kiely identifies this kind of Marxism as a dogma, and notes that it 'has rightly been identified as an example of the worst kind 
of Eurocentric, modernist arrogance, in which the "superior" west looks at the "inferior" Rest as a backward, stagnant and incomprehensible "other" (Kiely 1995: 23). Kiely also argues, however, that Marx himself provides an alternative comprehension of human development, which, I shall argue in the following section, was based on continually evolving and conflictual class relations.

\section{An Alternative Reading}

While the previous section suggests how Marx's thinking might be interpreted in determinist, Eurocentric and historically linear ways, this represents just one (bad) reading of his work. As Kevin Anderson (2010: 2) argues, whilst in the 1840s Marx held 'to an implicitly unilinear perspective, sometimes tinged with ethnocentrism... over time, his perspective evolved toward one that was more multilinear, leaving the future development of [peripheral] societies as an open question'. As will be argued below, Marx identified labouring class struggles and their interaction as a determinant of different societies' developmental trajectories.

\section{PRIMITIVE ACCUMULATION AND THE GLOBAL CONSTITUTION OF CAPITALISM}

In the last section of Capital Vol. 1 Marx provides a broad explanation for the rise of capitalism. It is particularly notable for its global, relational and class analytical emphasis:

'The discovery of gold and silver in America, the extirpation, enslavement and entombment in mines of the aboriginal population, the beginning of the conquest and looting of the East Indies, the turning of Africa into a warren for the commercial hunting of black-skins, signalled the rosy dawn of the era of capitalist production. These idyllic proceedings are the chief momenta of primitive accumulation'. (Marx 1990: 915)

Primitive accumulation was a globally integrated process, rather than one specific to a particular country or region. Contrary to Hobson's claim, the emergence of capitalism in Europe, was co-determined by the existence and reconstitution of an international division of labour. The establishment and (re)production of capitalist social relations in England, and Europe more generally, was therefore dependent upon globally interconnected labour systems:

'Direct slavery is just as much the pivot of bourgeois industry as machinery, credit, etc. Without slavery you have no cotton; without cotton you have no industry. It is slavery that has given the colonies their value; it is the colonies that have created world trade, and it is world trade that is the pre-condition of large-scale industry'. (Marx: 1846) ${ }^{9}$

Capital accumulation in Europe did not, Marx argued, benefit northern workers. Thus, 'Holland, which first brought the colonial system to its full development, already stood at the zenith of its commercial greatness by 1648 ' by which time its working class was 'more overworked, poorer, and more brutally oppressed than those of all the rest of Europe put together' (Marx 1990: 918).

Against those who wanted to turn Marx's insights into historical dogma, he insisted in Capital that the expropriation of the peasantry 'in different countries, assumes different aspects, 
and runs through its various phases in different orders of succession, and at different periods' (Marx 1990: 876). Towards the end of his life he wrote how his treatment of primitive accumulation in Capital 'claims no more than to trace the path by which, in Western Europe, the capitalist economic order emerged from the womb of the feudal economic order' (Marx, cited in Shanin 1983: 135).

Marx's analysis of primitive accumulation, the establishment of durable capitalist social relations, and how these processes entailed the creation and global integration of diverse labour systems, illuminates how his thinking about capitalism was essentially dialectical and precluded simplistic, linear, and determinist notions. It is far from any conception of expanding western economic and political power bringing progress in its wake. Equally, it undermines any expectation that late developing countries could follow a 'path' already established by the early capitalist states.

\section{AGAINST UNILINEARITY}

The critique of Marx as adhering to a unilinear and Eurocentric view of history rests upon statements such as 'The industrially more developed country shows the less developed only the image of its own future' (Marx, cited in Trotsky 1997: 1219). However, not only did Marx modify his views as he matured (Anderson 2010), but further, Capital was based upon a comprehension of a capitalist system, comprising a rapidly evolving international division of labour which discounted, a priori, a stagist process of human development (Pradella 2010). Marx also thought that struggles by labouring classes in the peripheral countries could impact decisively on the evolution of, and potential transcendence, of capitalism.

As we have seen, in his early writings on India, Marx (1853) wrote of England's 'double mission', 'one destructive, the other regenerating'. This is where Edward Said concentrates his fire, accusing Marx of Orientalism. But not only does Said downplay Marx's analysis of the possibilities of the Indians throwing off England's yoke, but he also misses Marx's later writings on Indian and broader Eurasian development. For example, Marx argued that:

'The Indians will not reap the fruits of the new elements of society scattered among them by the British bourgeoisie, till in Great Britain itself the... ruling classes shall have been supplanted by the industrial proletariat, or till the Hindoos themselves shall have grown strong enough to throw off the English yoke altogether'. (Marx 1853, emphasis added) ${ }^{10}$

Even here, at his most 'orientalist', Marx recognises Indians' agency, denied to colonized peoples by most bourgeois thinkers. He leaves as an open-ended question what kind of society (capitalist or post-capitalist) would emerge from a successful Indian uprising. Several years later when such an uprising did materialise (the Sepoy 'mutiny' of 1857), he wholeheartedly supported it, remarking to Engels that 'India is now our best ally'. ${ }^{11} \mathrm{He}$ similarly supported the Taiping rebellion in China interpreting it as part of a broader uprising by the Asiatic nations against British colonialism. As Pradella (forthcoming, 11) notes, Marx understood how these anticolonial movements impacted upon the capitalist core and elsewhere in the world system provoking crises for the bourgeoisie and giving an impulse to a number of social movements: in Russia for the suppression of servitude; in the United States for the abolition of slavery; while in Europe... workers began to mobilise again at syndicalist and political levels'. At the heart of 
Marx's dialectical conception of human development, then, was his analysis of conflictual class relations.

\section{Class Struggles and Human Development: Within, Against, Outside and Beyond Capitalism}

An economic determinist reading of Marx would suggest that he viewed economic growth and the development of the productive forces as the core determinant of human development. But, he argues more often than not against such conceptions. Rather, he demonstrated how class relations and struggles, their relation to the state, and how they are articulated within and through the world system, generate myriad forms and trajectories of human development. Situating class relations and struggles at the core of our analysis therefore provides a key vector along which to analyse divergent and differentiating forms of human development.

This section highlights four examples of Marx's thoughts about the diversity of class structures and struggles across the globe and their human developmental impacts. It highlights how he conceptualised these examples as embodying struggles against capitalism but not for socialism (in the Australian colonies), for improvements to workers' conditions under capitalism (Industrial England), within and against capitalism (the Commune in France), and outside and potentially beyond capitalism (in rural Russia).

As we shall see, Marx thought that socialist development on a world-scale was already possible in his time. This implies strongly that, for him, the development of the productive forces were already sufficient for socialist transformation, and that the key issue was not their further development under capitalism (as dogmatic forms of Marxism argued) but how a future, noncapitalist society would make use of capitalism's legacy of productive dynamism. Nevertheless, he also recognised that not all struggles by labouring classes were against capitalism and for socialism. This did not, however, reduce their importance to him. Rather, he analysed them in their specific context and in relation to the evolving world system, attempting to discern their developmental consequences for contemporary labouring classes (outlined in table 1). ${ }^{12}$

Table 1: Class Struggles and Divergent Human Development

\begin{tabular}{|ll|ll|}
\hline 1$)$ & $\begin{array}{l}\text { Anti-Capitalism in the Free Colonies } \\
\text { (Australia) }\end{array}$ & 3) & Communism (France) \\
\hline 2$)$ & $\begin{array}{l}\text { The Political Economy of Labour } \\
\text { (England) }\end{array}$ & 4) & $\begin{array}{l}\text { Non-Industrial Transitions to } \\
\text { Socialism (Russia) }\end{array}$ \\
\hline
\end{tabular}

Source: author 


\section{AUSTRALIA: ANTI-CAPITALISM IN THE FREE COLONIES ${ }^{13}$}

The protracted and contested process of primitive accumulation was particularly complicated in the so-called 'free colonies' - where the indigenous population had been dispossessed of the land (usually through extermination) but did not constitute the emerging wage labour force for capitalist production. This labour force was imported from the 'mother country' (or from its colonies). One such 'free colony' was Australia, where Marx observed how colonial capital experiences severe difficulties in establishing capitalist social relations, and how struggles against capitalist social relations took an anti-capitalist but not pro socialist form.

Marx notes how the fundamental difference between 'mother country' and 'free colony' is that whilst capitalist social relations have been established in the former by the 'expropriation of the mass of the people from the soil' in the latter, 'the bulk of the soil is still public property, and every settler on it can therefore turn part of it into his private property and individual means of production' (Marx 1990: 934). The implications of such opportunities of land acquisition for settlers that are in the 'mother country' capitalist production 'constantly reproduces the wageworker as wage worker... [and]... produces always... a relative surplus-population of wage workers' (ibid, 935). In the 'free colonies' however:

'On the one hand, the old world constantly throws in capital, thirsting after exploitation and 'abstinence'; on the other, the regular reproduction of wage-labour as wage-labour comes into collision with impediments the most impertinent and in part invincible... the wage-worker of today is tomorrow an independent peasant, an artisan, working for himself. He vanishes from the labour-market, but not into the workhouse'. (ibid, 936)

Consequently, Marx commented sardonically:

'This constant transformation of the wage-workers into independent producers, who work for themselves instead of for capital, and enrich themselves instead of the capitalist gentry, reacts in its turn very perversely on the conditions of the labour-market. Not only does the degree of exploitation of the wage-labourer remain indecently low. The wagelabourer loses into the bargain, along with the relation of dependence, also the sentiment of dependence on the abstemious capitalist'. (ibid, 936)

Attempts by dominant capitalist powers to extend capitalist social relations through territorial expansion thus generated new tensions and forms of class conflict, including attempts by newly imported workers to resist capitalist exploitation through escaping over the frontier. The latter's lack of real or felt sentiment of dependence upon capital represents for Marx the 'anticapitalist cancer of the colonies' (1990: 938 emphasis added). He quotes Edward Gibbon Wakefield, an English politician and leading figure in the colonisation of Australia, lamenting such sentiments and actions:

'Where land is very cheap and all men are free, where everyone who so pleases can easily obtain a piece of land for himself, not only is labour very dear, as respects the labourer's share of the produce, but the difficulty is to obtain combined labour at any price' (Wakefield, cited in Marx 1990, ibid: 934-5). 
The solution to the difficulties of establishing a fully functioning capitalist labour market where wage workers are compelled to sell themselves to the capitalist is to cut off their access to the land through the state putting 'upon the virgin soil an artificial price, independent of the laws of supply and demand, a price that compels the immigrant to work a long time for wages before he can earn enough money to buy land, and turn himself into an independent peasant' (Marx 1990: 938). In addition to pricing wage-labourers out of the land market the colonial state played a significant role in pushing down wages in the urban industrial centres in order to strengthen the dependence of workers on the labour market (Cowan and Shenton 1996). As Gavin Capps notes in relation to the Australian case, but with a broader historical relevance: 'The creation of a fully proletarianised working-class, regulated autonomously by the 'dull compulsion' of market forces, is... a volatile, uncertain and historically protracted process, and one that is constantly violated by... political interventions' (Capps 2010: 81). This then raises the question of what kinds of workers' struggles could come forth where capitalist socialist relations had been firmly established?

\section{ENGLAND: THE POLITICAL ECONOMY OF LABOUR ${ }^{14}$}

In his analysis of the English industrial working class Marx developed his conception of the political economy of labour - introduced in his 1864 Inaugural Address to the First International. Here he reveals a rival political economy to that of Capital. He began his address by critiquing the then (and now) commonly held assumption of the causal relationship between economic growth and enhanced human wellbeing. Speaking about the English experience, he argued that:

'It is a great fact that the misery of the working masses has not diminished from 1848 to 1864 , and yet this period is unrivalled for the development of its industry and the growth of commerce'. ${ }^{15}$

Rather than capital accumulation generating trickle-down mechanisms leading to distribution of wealth amongst workers, Marx presented an altogether different picture. Capitalist growth and expansion represents the continued and deepening subordination of labour to its (re)productive requirements. As Lebowitz argues '[C]apital does not merely seek the realisation of its own goal, valorisation; it also must seek to suspend the realisation of the goals of wage-labour' and that a 'necessary condition for the existence of capital is its ability to divide and separate workers - in order to defeat them' (Lebowitz 1992: 85). In an ideal world for capital:

'What the lot of the labouring population would be if everything were left to isolated, individual bargaining, may be easily foreseen. The iron rule of supply and demand, if left unchecked, would speedily reduce the producers of all wealth to a starvation diet'. (Marx $1867)^{16}$

However, workers' organisations contradict these rules and potentially represent an alternative political economy. Collective gains against capital are won through 'negating competition, [and] infringing on the "sacred" law of supply and demand and engaging in "planned co-operation" (Lebowitz 1992: 67, citing Marx). 
Marx provides two examples of the political economy of labour in his inaugural address to the first International. The first example, the Ten-Hours Act (introduced in England in 1847 which legally reduced the working day to a maximum of ten hours), was the first time that in broad daylight the political economy of the [capitalist] class succumbed to the political economy of the working class' (Marx 1864). ${ }^{17}$ The second example was the creation of worker-run cooperative factories. The latter were of great significance because ' $[b] y$ deed instead of by argument... [such organisations]... have shown that production on a large scale, and in accord with the behests of modern science, may be carried on without the existence of a class of masters employing a class of hands' (ibid). Whilst capitalists always need workers the reverse is not the case. Barker (2006: 68) notes that other principles of the political economy of labour include, negating competition between workers, restricting capital's coercive control in the workplace, maintaining the 'normal' working day, and reducing the rate of surplus value extraction.

Marx demonstrated here how workers' struggles are developmental in that by ameliorating their present conditions through their own actions they do not have to wait for an unspecified time in the future for benefits to trickle down to them. Whilst these examples still pre-supposed the continued existence of capitalism, in his discussion of the Paris Commune Marx observed a movement that he identified as having the potential to transcend capitalism altogether.

\section{FRANCE: COMMUNISM}

Within Marx's lifetime labour's greatest victory over capital was achieved through the Paris Commune of 1871. The Commune emerged within a context of a political crisis in France. Napoleon $3^{\text {rd }}$ had suffered a catastrophic defeat at the hands of Bismarck's Prussian army with most of his army taken captive. He was subsequently overthrown. Possessing neither political cohesion nor available military force the French state encountered a situation of rapidly diminishing authority, which it attempted to alleviate through turning to the Parisian working class (Gluckstein 2006).

The working class of Paris represented the majority of the city's population, and unlike in Manchester, laboured in a mass of tiny workshops: 'Sixty percent of economic units consisted of just two workers, while only 7 percent had more than ten' (Gluckstein 2011: 35; Gaillard 1977). David Harvey describes the distinct form that capitalist development took in Paris:

'Many small firms were nothing more than subcontracting units for larger forms of organisation...[B]y keeping these units perpetually in competition for work, the employers could force down labour costs and maximise their own profits. Workers, even though nominally independent, were forced into subservience and into patterns of selfexploitation that could be as savage and as degrading as anything to be found in the factory system'. (Harvey 2003: 160)

Harvey also describes how the proliferation of small businesses partially determined the mode of Parisian worker's resistance to capitalism: 'They continued to exercise collective pressure on labour markets, largely by staying put in their traditional quarters... Industries that needed their skills had to go to them' (ibid, 174).

The fragmentation of the Parisian working class, however, was transformed into political concentration in response to the Prussian army's siege of the city. In the context of rapidly 
deteriorating economic conditions, the government armed the workers who quickly constitued the majority of the National Guard. As Gluckstein puts it ' $t$ ] hus the Parisian working class acquired a collective organisation, even if by a highly peculiar route' (2011: 35). Their neighbourhood-based forms of class action constituted the core of the Commune.

National Guard officers were elected and rank and file soldiers enjoyed unprecedented democratic control. Once the French government had agreed a peace with Prussia, however, the government saw the Guard as representing a mortal threat to its rule and attempted, in March 1871 , to disarm it. But this sparked a revolt by the Guard and the wider working class population of Paris, leading to the establishment of the Commune. The day after the rising a French newspaper described it as:

'Without example in history. Your revolution has a special character that distinguishes it from others. Its... greatness is that it is made entirely by the people as a collective communal revolutionary undertaking... for the first time without leaders...This is a natural power, spontaneous, not false; born from the public conscience of the 'vile multitude' which has been provided and attacked and now legitimately defends itself. ( $\mathrm{La}$ Commune 1871, cited in Gluckstein, ibid: 35)

During its brief two-month life the standing army was abolished, municipal councillors, public servants, magistrates and judges were elected and subject to recall, the police were 'stripped of its political attributes, and turned into the responsible, and at all times revocable, agents of the Commune' (Marx 1871 and Gluckstein 2011). The Commune's civil servants received worker's wages. The commitment to human development was perhaps most evident in the Commune's education policy:

'The whole of the educational institutions were opened to the people gratuitously, and... cleared of all interference of church and state [and]... science [was] itself freed from the fetters which class prejudice and governmental force had imposed upon it'. (Marx 1871) ${ }^{18}$

Marx did not believe that the Commune represented the imminent transformation of an exploitative class-based society, with its extreme economic and political unevenness, directly into a non-class, communist utopia. On the contrary, he viewed it as potentially only the beginning of a long and protracted transitional process:

'The working class did not expect miracles from the Commune... They know that in order to work out their own emancipation... they will have to pass through long struggles, through a series of historic processes, transforming circumstances and men'. (ibid)

The transformative possibilities of the Commune were not lost on the French and other European ruling classes. As Benedict Anderson (2004: 94) writes:

'In March 1871 the Commune took power in the abandoned city and held it for two months. Then Versailles seized the moment to attack and, in one horrifying week, executed roughly 20,000 Communards or suspected sympathizers, a number higher than those killed in the recent war or during Robespierre's 'Terror' of 1793-94'. 
Bismarck, presiding over his newly established German state following the previous years' victory against France, put aside international rivalries and freed thousands of French prisoners of war to join the Versailles-led destruction of the Commune (Harman 1999). The defeat of the Commune pushed Marx to consider other sources of socialism, geographically beyond Europe and potentially achieved by actors other than industrial working classes.

\section{RUSSIA: NON-INDUSTRIAL TRANSITIONS TO SOCIALISM}

In his commentaries on non-Western societies discussed above, Marx viewed revolt in India and China as leading to a number of possible outcomes. These included the possibilities of national unification under Indian and Chinese rule respectively, and subsequent national capitalist development, or their revolts stimulating revolutionary upheavals in Europe, which in turn might signal the beginnings of the world-wide development of socialism. In these observations, Marx still posits industrial(ising) Europe as the potential starting point for socialism. If these represented his most mature considerations, then the argument that he privileged the Western European proletariat in a Eurocentric manner might have some traction. But he went significantly further than this. Towards the end of his life in his writings on Russia, he raised an altogether new possibility of human development.

Marx became interested in the pattern of Russian development after the publication of Capital in Russian (in 1872) and the intense interest it generated amongst agrarian populists (Shanin 1983). Their leading figures such as Herzen and Chernyshevsky argued that the specifically cooperative nature of the Russian commune (Obschina or Mir) rendered it fit for laying the basis for a post-capitalist society in Russia, despite the country's very low level of capitalist development. ${ }^{19}$ In 1881 Vera Zasulich (also a populist and a member of Russia's socialist party) wrote to Marx asking whether 'the rural commune, free of exorbitant tax demands, payment to the nobility and arbitrary administration, is capable of developing in a socialist direction' or whether 'the commune is destined to perish' (in Shanin 1983: 98), and whether socialists needed to wait for the full development of Russian capitalism before attempting socialist revolution. The latter position was held by most of Marx's Russian followers (Day and Gaido 2011: 24-32). Marx's response demonstrates his dialectical view of world history, and his recognition of the potential agency of labouring classes in the periphery:

'If Russia were isolated in the world, it would have to develop on its own account the economic conquests which Western Europe only acquired through a long series of evolutions from its primitive communities to its present situation... There would be no doubt... that Russia's communities are fated to perish'. (Marx, in Shanin 1983: 102)

But:

'[T] he situation of the Russian commune is absolutely different from that of the primitive communities in the West... ...Russia is the only European country in which communal property has maintained itself on a vast, nationwide scale. But at the same time Russia exists in a modern historical context [International capitalism].... Thanks to the unique combination of circumstances in Russia, the rural commune... may gradually shake off its 
primitive characteristics and directly develop as an element of collective production on a national scale'. (Marx, in Shanin 1983: 102)

Marx identified how the rural commune contained an internal tension. On the one hand communal landownership held it together, whilst on the other hand individual (family) ownership of the house and yard combined with small-plot farming and the 'private appropriation of its fruits' maintaining a level of individualism potentially incompatible with communal life. Marx saw this tension as containing a potential contradiction as eventually it 'could turn into a seed of [the Commune's] disintegration'. Of additional importance was the existence of 'fragmented labour as the source of private appropriation' not subject to communal control and open to individual exchange. Marx observed that 'This was what dissolved primitive economic and social equality' (Marx, in Shanin 1983: 120).

The dissolution of the commune was possible but not inevitable. The outcome depended on struggles within and beyond the commune and Russia. "What threatens the life of the Russian commune is neither an historical inevitability nor a theory; it is oppression by the state and exploitation by the capitalist intruders made powerful, at the expense of the peasantry by this same state' (ibid, 104-5). To save the Russian commune, Marx argued:

'[T] here must be a Russian revolution... If the revolution takes place in time... to ensure the unfettered rise of the rural commune, the latter will soon develop as a regenerating element of Russian society and an element of superiority over the countries enslaved by the capitalist regime' (Marx, in Shanin 1983: 116-117).

This revolution could not stop at the Russian border however. It had to extend beyond it and required revolution by workers of the advanced capitalist countries. Indeed, Marx hoped that such a revolution in Russia would stimulate revolution in the west, thus unleashing a new form of human development, communism, emerging from combinations of industrially organised workers in the west and agrarian communes in the east:

'If the Russian revolution becomes the signal for a proletarian revolution in the West, so that the two complement each other, then Russia's peasant communal landownership may serve as the point of departure for a communist development'. (Marx, cited in Shanin 1983: 139)

Here Marx recognises the agency of labouring classes East and West to transform their own forms and trajectories of human development, with no presupposition that either must follow an already established path or schema of events. Significantly, Marx considered socialism emerging as a consequence of combinations of (at least) agrarian and industrial based movements by very differently constituted labouring classes. This shows that Marx did not think that only western industrial workers could breach capitalist social relations, and how he conceived the emergence of socialism as a globally constituted moment of world history, based upon the interacting struggles of labouring classes North, South, East and West. 


\section{Conclusions}

We have seen how within Marx's work there are elements of an economic determinist, Eurocentric and linear comprehension of history. Much worse still is the way these elements have been elevated into a seemingly coherent orthodox dogma that leaves little or no room for the labouring classes of the global south to determine their own fate. If Marx is interpreted as a Eurocentric economic determinist then the intellectual mediocrities of the past century - from Stalinists to neo-liberals - have won the day, and an immensely powerful tool for struggling for and achieving alternative forms of human development will be lost. These interpretations are, however, contradicted by the broader sweep of Marx's work.

The purpose of this article has been to suggest that a reading of Marx centred upon his understanding of evolving and continually dynamic class relations and struggles, and their global interactions, renders untenable the above critique. It also provides the basis for a labour-centred conception of development and development studies.

A labour-centred approach to development studies would entail investigating processes of capitalist establishment, reproduction, and potential transcendence, from the perspective of labour. It would, for example, investigate the struggles by capital and states to establish durable capitalist social relations, and how these attempts are resisted. It would also investigate how the settlement of these struggles is institutionalised (how they frame the subsequent actions of capital, state, and labour), and the developmental trajectories that these settlements give rise to. It could seek to investigate how labouring class struggles are determined by, but also determine, forms of capitalist restructuring and how such struggles can contribute to the human development of emerging or established labouring classes.

In his writings on non-western societies Marx showed how their interconnections with the imperial centres ushered in a new phase of human history whereby the actions of labouring classes in the periphery could impact significantly upon the forms of social development in the global core. The struggles against imperialism in China and India, Marx argued, could lead to intensification of class struggles in the global core, and/or to the potential establishment of capitalist states in these countries. Marx's analysis of Australian colonisation demonstrated how essential the colonial state was in establishing capitalist social relations there. Without such actions there were possibilities that the newly established working classes would escape their subordination to capital and establish themselves as independent peasantries beyond the frontier. Moreover, the persistence of the commune in Russia generated the possibility of a leap to socialism initiated by non-industrial labouring classes, and their playing the leading role in broader European revolutions against capitalism.

Marx's writings on the political economy of labour and on the Paris Commune are of potentially even greater importance under contemporary global capitalism. In the former, Marx highlighted how workers could generate movements that would substantially improve their livelihoods under capitalism. And in the organisation of the Commune, he argued that workers had finally found the political-economic structure through which to liberate themselves from the chains of capital.

Manchester, Paris (and Birmingham) represented diverse forms of capitalist industrialisation in the capitalist core. Manchester consisted of large-scale factories and workplace based labour militancy, while Paris consisted of myriad small workshops, widespread 'informal' work, and of neighbourhood organisations that became the organising hub of the Commune. 
These examples are arguably more relevant today than those of colonial Australia or rural Russia because global capitalism has created a world working class of billions (compared to the few millions of Marx's day) whose livelihoods are much closer to those of the Manchester textile workers or the Parisian Communards than to the non-capitalist Russian commune or the Australian frontier. Moreover, through globalised production systems, the modern day equivalents to Marx's Manchester, Birmingham and Paris, whilst geographically dispersed and displaying myriad labour systems, are functionally integrated in novel ways. This functional integration not only provides labour with the potential to disrupt globalised capital accumulation, by strategic action at specific points within global production networks, but it also means that workers can potentially identify with each other's conditions, as they are subject to ever-similar imperatives, as exemplified in the risings in Latin America, the Middle East, China and beyond.

However, Marx's discussions of the agrarian social formations and movements during his lifetime alert us to the importance of continuing struggles by labouring classes in the contemporary rural world, and raises questions of how sustainable they are on their own terms, what kinds of alliances can be built between them and other labouring classes (in urban settings and/or internationally), and of course, what kinds of contradictions arise in these, as in all, class struggles.

In all of these considerations - of struggles from above for the establishment, consolidation and reproduction of capitalist social relations and from below against exploitation and potentially for socialism - Marx's comprehension of human development is fundamentally different from mainstream liberal or statist conceptions of development. Marx is the key figure who saw conflictual class relations as constitutive of the development process and who demonstrated how the outcomes of struggles between dominant and labouring classes conditioned subsequent historical development. Moreover, he identified with and politically prioritised the labouring classes in their attempts to rid themselves from capitalist exploitation. For these reasons Marx's political economy potentially represents a powerful tool for contemporary labouring classes across the globe who are struggling for meaningful and sustainable human development under, and potentially beyond capitalism.

\section{NOTES}

1. See Selwyn (2009, 2011a and 2011b) for further critiques of these approaches.

2. http://www.marxists.org/archive/marx/works/1848/communist-manifesto/ch02.htm. (Accessed 10 July 2012).

3. See, for example, a recent discussion in the Economist (2011). Available at: http://www.economist.com/node/18682182. (Accessed 15 May 2012).

4. Marx (1847) Wage Labour and Capital. Available at http://www.marxists.org/archive/marx/works/1847/wage-labour/ch09.htm. (Accessed 20 April 2012). 
5. Available at: http://www.socialistworker.co.uk/article.php?article_id=8683. (Accessed 15 May 2012).

6. Kiely (1995, chapter 2) provides an excellent account of the limitations of economic reductionist Marxism in the study of development.

7. Available at: http://www.marxists.org/archive/marx/works/1853/06/25.htm. (Accessed 10 July 2012).

8. Available at: http://www.marxists.org/archive/marx/works/1848/communistmanifesto/ch01.htm\#007. (Accessed 10 July 2012).

9. Available at: http://www.marxists.org/archive/marx/works/1846/letters/46_12_28.htm. (Accessed 12 July 2012).

10. (Marx 1853) available at: http://www.marxists.org/archive/marx/works/1853/07/22.htm. (Accessed 10 July 2012).

11. Marx-Engels Correspondence 1858, available at: http://www.marxists.org/archive/marx/works/1858/letters/58_01_16.htm. (Accessed 20 July 2013).

12. The following section is not intended as a complete account of Marx's considerations of different forms of class struggles. See Anderson (2010) for a good overview.

13. I am indebted to Gavin Capps for some very useful discussions on this question.

14. The foremost theorist of the political economy of labour is Michael Lebowitz (1992).

15. http://www.marxists.org/archive/marx/works/1864/10/27.htm. (Accessed 12 July 2012).

16. Available at: http://www.marxists.org/archive/marx/iwma/documents/1867/affiliates.htm. (Accessed 2 March 2012).

17. Available at http://www.marxists.org/archive/marx/works/1864/10/27.htm. (Accessed 3 April 2012).

18. Available at http://www.marxists.org/archive/marx/works/1871/civil-war-france/index.htm. (Accessed 5 April 2012).

19. Kitching (1989) provides an excellent discussion of these early populist writers. 


\section{REFERENCES}

Anderson, B. (2004) 'In The World-Shadow of Bismarck and Nobel', New Left Review 28(JulyAugust): 85-129.

Anderson, K. (2010). Marx at the Margins: On Nationalism, Ethnicity and Non-Western Societies. Chicago: University of Chicago Press.

Barker, C. (2006) 'Capital and Revolutionary Practice'. Historical Materialism 14(2): 55-82.

Bernard, M. and Ravenhill, J. (1995) 'Beyond Product Cycles and Flying Geese: Regionalization, Hierarchy, and the Industrialization of East Asia', World Politics 47 (January): 171-209.

Bernstein, H. (2010) 'Can Modernity Accommodate African 'Peasants'? Paper delivered at the $7^{\text {th }}$ Congress of African Studies, Lisbon 2010.

Binns, P. and Gonzalez, M. (1980) Cuba, Castro and Socialism. International Socialism Journal 2(8): $1-36$.

Burkett, P. and Hart-Landsberg, M. (2003) 'A Critique of "Catch-Up" Theories of Development', Journal of Contemporary Asia 33 (3): 147-171.

CAFOD (2004) 'Clean up Your Computer: Working Conditions in the Electronics Industry', M, Itoh, R, Westra and A, Zuege (eds). London: CAFOD.

Cammack, P. (2002) 'Attacking the Poor'. New Left Review 13(January-February): 125-134.

Capps, G. (2010) Tribal Landed Property: The Political Economy of the BaFokeng Chieftaincy, South Africa, 1837-1994. Phd Thesis, London School of Economics, London, UK.

Cliff, T. (1974) State Capitalism in Russia. London: Bookmarks.

Cowen, M. and Shenton, R. (1996) Doctrines of Development. London: Routledge.

Day, R. and Gaido, D. (eds) (2011) Witness to Permanent Revolution. Leiden: Brill.

Eisenstadt, S.N. (2000) 'Multiple Modernities'. Daedulus 129 (1): 1- 29.

Dunn, B. (2005) Global Restructuring and the Power of Labour. Basingstoke, UK: Palgrave Macmillan.

Freeman, R. (2006). 'The Great Doubling: The Challenge of the New Global Labour Market', draft, Harvard University, August 2006. Available at: 
http://emlab.berkeley.edu/users/webfac/eichengreen/e183_sp07/great_doub.pdf. (Accessed 21 July 2012).

Gaillard, J. (1977) Paris, La Ville 1852-1870. Lille-Paris, Honoré Champion.

Gereffi G. (2001) 'Shifting Governance Structures in Global Commodity Chains, With Special Reference to the Internet', American Behavioral Scientist 44(10): 1616-1637.

Gluckstein, D. (2006). The Paris Commune: A Revolution in Democracy. London: Bookmarks.

Gluckstein, D. (2011) 'Workers' Councils in Europe: A Century of Experience', in I. Ness and D. Azzellini (eds), Ours to Master and to Own: Workers' Control from the Commune to the Present (pp. 32-47). Chicago: Haymarket.

Harman, Chris. 1974 Bureaucracy and Revolution in Eastern Europe. London: Bookmarks.

Harman, C. (1999) A People's History of the World. London: Bookmarks.

Hanieh, A. (2011) 'Egypt's Uprising: Not Just a Question of “Transition”', The Bullet EBulletin (462) 14 February. Available at: http://mrzine.monthlyreview.org/2011/hanieh140211.html. (Accessed 20 March 2011).

Hardt, M. and Negri, T. (2000) Empire. Cambridge, MA: Harvard University Press.

Harvey, D. (2003). Paris, Capital of Modernity. New York and London: Routledge.

Harvey, D. (2010). A Companion to Marx's Capital. London: Versa.

Hobson, J. (2011) 'What's at Stake in the Neo-Trotskyist Debate? Towards a Non-Eurocentric Historical Sociology of Uneven and Combined Development'. Millennium - Journal of International Studies 40(1): 147-166.

Hore, C. (1991). The Road to Tiananmen Square. London: Bookmarks.

Kiely, R. (1995) Sociology and Development: The Impasse and Beyond. London: Routledge.

Kitching, G. (1989) Development and Underdevelopment in Historical Perspective. London: Routledge.

Lebowitz, M. (1992) Beyond Capital: Marx's Political Economy of the Working Class. London: MacMillan.

Marx, K. (1942). 'The Industrialists of Hanover and Protective Tariffs'. Rheinische Zeitung No. 326, 22 November $1842 . \quad$ Available at: http://www.marxists.org/archive/marx/works/1842/11/22.htm. (Accessed 10 July 2011). 
Marx, K. 1853). 'The Future Results of British Rule in India'. New-York Daily Tribune, 8 August 1853. Available at: http://www.marxists.org/archive/marx/works/1853/07/22.htm. (Accessed 10 July 2011).

Marx, K. (1990) Capital, Vol. 1. London: Penguin.

Marx, K. (1847) Wage Labour and Capital. Available at: http://www.marxists.org/archive/marx/works/1847/wage-labour/ch09.htm. (Accessed 20 April 2012).

Marx, K. (1847). The Free Trade Congress at Brussels'. The Northern Star, no. 5 October 1847. Available at: http://www.marxists.org/archive/marx/works/1847/09/30.htm. (Accessed 6 July 2011).

Marx, K. (1848a) On the Question of Free Trade. Available at: http://www.marxists.org/archive/marx/works/1848/01/09ft.htm (Accessed 6 July 2012).

Marx, K. (1871) The Civil War in France: March - May 1871. Available at: http://www.marxists.org/archive/marx/works/1871/civil-war-france/index.htm. (Accessed 15 July 2011).

Marx, K and Engels, F. (1848) The Manifesto of the Communist Party. Available at: http://www.marxists.org/archive/marx/works/1848/communist-manifesto/. (Accessed 10 July 2011).

Marx, K. (1864) 'Inaugural Address of the International Working Men's Association'. Available at: http://www.marxists.org/archive/marx/works/1864/10/27.htm. (Accessed 12 July 2011).

Marx, K. (1846) 'Letter from Marx to Pavel Vasilyevich Annenkov in Paris'. Available at: http://www.marxists.org/archive/marx/works/1846/letters/46_12_28.htm. (Accessed 5 March 2012).

Marx, K. (1867) 'Rules and Administrative Regulations of the International Workingmen's Association (1867)'. Available at: http://www.marxists.org/archive/marx/iwma/documents/1867/rules.htm. (Accessed 12 July 2012).

Marx, K and Engels, F. (1975) Selected Correspondence. Moscow. Progress Publishers.

Marx, K. (1929) 'Marx-Engels Correspondence 1858', in Marx and Engels, Works, Moscow, 1929. Available at: http://www.marxists.org/archive/marx/works/1858/letters/58_01_16.htm. (Accessed 11 July 2011). 
Marx, K. (1881) 'Drafts of a Reply to Vera Zasulich', in T, Shanin (1983) Late Marx and the Russian Road (pp. 97-126). New York: Monthly Review Press.

Panitch, L and Leys, C. (2000) 'Preface', in L, Panich and C, Leys (eds) The Socialist Register 2001 (pp. v11-x1). London: Merlin.

Plekhanov, G. (1976) The Materialist Conception of History. London: Lawrence and Wishart.

Pradella, L. (2010) L'attualità del Capitale. Accumulazione e impoverimento nel capitalismo globale. Padova: Il Poligrafo.

Pradella, L. (forthcoming). 'Imperialism and Capitalist Development in Marx's Capital', Historical Materialism.

Said, E. (1993) Culture and Imperialism. London: Vintage.

Said, E. (2003) Orientalism. London: Penguin.

Shanin, T (ed) (1983) Late Marx and the Russian Road: Marx and the 'Peripheries' of Capitalism. New York: Monthly Review Press.

Selwyn, B. (2008) 'Bringing Social Relations Back In: (Re)conceptualising the "Bullwhip Effect" in Global Commodity Chains', International Journal of Management Concepts and Philosophy 3(2): 156-175.

Selwyn, B. (2009) 'An Historical Materialist Appraisal of Friedrich List and his Modern-Day Followers', New Political Economy 14(2): 157-180.

Selwyn, B. (2011a) 'Liberty Limited? A Sympathetic Re-Engagement with Amartya Sen's Development as Freedom', Economic and Political Weekly September 46(37): 68-76.

Selwyn, B. (2011b) 'Trotsky, Gerschenkron and the Political Economy of Late Capitalist Development', Economy and Society 40(3): 421-450.

Selwyn, B. (2012) Workers, State and Development in Brazil: Powers of Labour, Chains of Value. Manchester: Manchester University Press.

Silver, B and Zhang, L. (2009) 'China as an Emerging Epicentre of World Labour Unrest', in H.-F. Hung (ed), China and the Transformation of Global Capitalism (page nos?). Baltimore: Johns Hopkins Press.

Standing, G. (2011) The Precariat: The New Dangerous Class. London: Bloomsbury.

Trotsky, L. (1997). The History Of The Russian Revolution. London: Pluto. 
Webber, J. (2011) From Rebellion to Reform in Bolivia: Class Struggle, Indigenous Liberation, and the Politics of Evo Morales. Chicago: Haymarket Books.

Wolf, M. (2005) Why Globalization Works: The Case for the Global Market Economy. Yale: Nota Bene.

Zeilig, L. (2010) 'Tony Cliff: Deflected Permanent Revolution in Africa', International Socialism 126. Available at: www.isj.org.uk/?id=641. (Accessed March 20 2011).

Zibechi, R. (2006) 'El Alto: The Heights of the Bolivian Movement', Socialist Worker. Available at: http://www.socialistworker.co.uk/article.php?article_id=8683. (Accessed 15 May 2012).

\section{BIOGRAPHICAL NOTE}

BENJAMIN SELWYN is Senior Lecturer in International Relations and Development Studies in the Department of International Relations, University of Sussex, Brighton, UK. He is the author of Workers, State and Development in Brazil: Powers of Labour, Chains of Value (Manchester University Press, 2012). He is completing his book Capitalism vs Development: Critiques and Alternatives for publication in 2014. [e-mail: B.Selwyn@sussex.ac.uk] 